\title{
Failures of the Export Markets of the African Mango to Europe: Theoretical and Empirical Causes
}

(Research Article)

Afrika Mangosunun Avrupa'ya İhraç Pazarlarındaki Zayıflıklar: Teorik ve Ampirik Nedenler

Doi: 10.29023/alanyaakademik.472119

\section{Ferdinand OUEDRAOGO}

Assistant Professor at the University Ouaga II Burkina Faso.

Email: ouedraogo.ferdinand@yahoo.fr Tel: +22670260075

Orcid No: 0000-0002-1711-2055

How to cite this article: Ouedraogo, F. (2019). Failures of the export markets of the African mango to Europe: theoretical and empirical causes. Alanya Academic Review, 3(1), 35-47.

Keywords

Mangoes, Exports, Contracts, Failures, Causes, Conséquences, Solutions.

Received: 18.10 .2018 Accepted: 12.12 .2018

\begin{abstract}
The objectives of this study are to demonstrate the failures of African mango export markets, to analyze the causes and characteristics to study the impact on the behavior of importing and exporting agents and to propose solutions. The findings of the study showed that standardized firm contracts with shared costs and benefits are contracts of incentives for transparency and the reduction of fraud in transactions, while standardized firm contracts with unevenly distributed costs and benefits, are contracts of incentives for the inertia and darkening of the international market for African exporters. The choice of the type of contract by the exporter depends on his level of commitment to the risks as riscophilous, riscophobic or risk-neutral agent. The study recommended solutions.
\end{abstract}

\section{INTRODUCTION}

In international trade, the European Union is the most important trading partner of West Africa before China, the United States and India. Statistics show that $37.8 \%$ of West African exports go to the European Union, and $24.2 \%$ of West African imports come from the EU. However, West Africa accounts for only $2 \%$ of the EU's international trade, ie $2.2 \%$ of its imports and $1.8 \%$ of these exports.

From 2010 to 2014, European imports from West Africa increased by $14.2 \%$ (annual average), and European exports to West Africa increased by $7.7 \%$ (annual average). With the Economic Partnership Agreements concluded with the European Union in 2014, West African countries thought that they had finally broken down the trade barriers hindering the entry of African products into Europe. Unfortunately, the rejections of African exports for non-compliance with sanitary regulations are still relevant since the signing of these agreements. The persistence of interceptions, export rejections and the resulting economic losses since the signing of these agreements are clear proof that West African export markets to the European Union are failing. However, authors of economic theories such as Akerlof (1970), Spence (1974), Coase (1960) and North (1994) justified the market failures by the 
existence of imperfect information problems between the actors, the existence market power and high transaction costs. The objective of this study is to prove the failures of the export markets for African products, particularly those of mangoes, by analyzing its characteristic elements, to verify that imperfect information on quality, prices, availability of mangoes Export costs, transaction costs and high market power are critical components of the bankruptcy of these markets, and the behavior of market participants is changed each time they face uncertainties and risks.

Thus a first section of this paper entitled "Failure of African export markets to the European continent: analysis of the characteristic elements" is an analysis of the weight of West African exports in the international trade of the European Union, then an identification and an analysis of the growth of interceptions and discards of cargoes of mangoes at the borders of European Union countries. A second section entitled "Materials and methods of the study" presents a review of the literature review on the risks of interceptions and rejections of cargoes of mangoes at the borders of European countries, the development of the economic theories underlying the market failures and their theoretical causes. A final section entitled "Results obtained from the study and discussion" is devoted to the identification and analysis of the causes of malfunctioning mango export markets, the choice of the type of contract and the expected gain of the mango exporter faced with an imperfect risk and information situation, and then with an interpretation and discussion of the results obtained. The study is completed by a series of conclusions and recommendations for economic policies.

\section{FAILURES of AFRICAN EXPORT MARKETS to the EUROPEAN CONTINENT: ANALYSIS of CHARACTERISTIC ELEMENTS}

This section is firstly an analysis of the weight of West African exports in international trade of the European Union, then an analysis of the growth of interceptions and rejections of mango cargoes at European borders and economic consequences.

\subsection{The low level of West African exports in the international trade of the European Union}

In international trade, the European Union is the most important trading partner of west Africa before China, the United States and India. Statistics show that $37.8 \%$ of West African exports go to the European Union, and $24.2 \%$ of West African imports come from the EU. However, West Africa accounts for only $2 \%$ of the EU's international trade, ie $2.2 \%$ of its imports and $1.8 \%$ of these exports.

From 2010 to 2014, European imports from West Africa increased by $14.2 \%$ (annual average), and European exports to West Africa increased by $7.7 \%$ (annual average). In 2010, in terms of illustration, the potential for production of fresh mangoes in West Africa was estimated at around 810000 tons with potential for export to the European Union.

Table 1. Evolution of mango exports from 2004 to 2014 (in tons)

\begin{tabular}{llllllllllll}
\hline Pays & $\mathbf{2 0 0 4}$ & $\mathbf{2 0 0 5}$ & $\mathbf{2 0 0 6}$ & $\mathbf{2 0 0 7}$ & $\mathbf{2 0 0 8}$ & $\mathbf{2 0 0 9}$ & $\mathbf{2 0 1 0}$ & $\mathbf{2 0 1 1}$ & $\mathbf{2 0 1 2}$ & $\mathbf{2 0 1 3}$ & $\mathbf{2 0 1 4}$ \\
\hline $\begin{array}{l}\text { Côte } \\
\text { d'ivoire }\end{array}$ & 12091 & 11113 & 15374 & 14706 & 11250 & 11680 & 11129 & 10105 & 15289 & 14900 & 20475 \\
Sénégal & 2810 & 3011 & 6194 & 4702 & 6034 & 6240 & 2758 & 5338 & 6200 & 8205 & 10247 \\
Mali & 2170 & 3048 & 8554 & 4317 & 4902 & 3480 & 3672 & 1283 & 2983 & 4800 & 3833 \\
Burkina & 838 & 1181 & 2172 & 3191 & 2406 & 1988 & 3304 & 1664 & 1755 & 2700 & 3064 \\
Faso & & & & & & & & & & & \\
\hline
\end{tabular}

Source: ITC Trade Map 
In 2015, exports of West African mangoes accounted for one-third of world exports (AFD 2015).

\subsection{Growth of interceptions and rejections of mango cargoes and economic consequences}

Standards and regulations are established to govern the quality of products of the fruit and vegetables sector imported by the countries of the European Union. Regarding the export of mango to the countries of the European Union, there is, among other things, CODEX STAN 184-1993, AMD, 1-2005, defining the minimum characteristics of the quality of mango, their categorization, sizing, quality tolerances, size tolerances, uniformity and packaging, marking and labeling, contaminants including pesticide residues, hygiene, Regulation (EC) No 852/2004 of the European Parliament and Council and the European Council concerning hygiene for all foodstuffs from production to distribution. Failure to comply with these standards and regulations leads to interceptions and systematic rejections of exports at the entry of Europe. Interceptions leading to the rejection of mango exports to the border of European countries are due to revelations of information on the quality of exported mangoes including the presence of harmful elements but also to revelations of questionable information on the quality of these exports of mangoes as for example, absence, noncompliance and unreliability of quality certification documents, such as phytosanitary certificates, bulletins, etc. Indeed, interceptions related to non-compliance of export documents accounted for $23 \%$ of total interceptions between 2005 and 2015. In 2014, there were 112 interceptions of infected mangoes from Africa and 72 interceptions of mangoes coming from Africa. ACP countries, unfit for consumption from the point of view of European standards, the 52 come from the African space (Ousseini S., ECOWAS, 2015). In the space of about ten years (2005 to 2015) the number of interceptions has been multiplied by 5 for all four countries studied: Mali, Burkina Faso, Côte d'Ivoire, and France. Senegal. However, Burkina Faso is the country of West Africa breaking the record with a multiplication of its interceptions by 16 against a multiplication of its level of exports of mangoes by 7 .

Table 2. Evolution of total interceptions from 2005 to 2015

\begin{tabular}{lccccccccccc}
\hline Pays / Années & $\mathbf{2 0 0 5}$ & $\mathbf{2 0 0 6}$ & $\mathbf{2 0 0 7}$ & $\mathbf{2 0 0 8}$ & $\mathbf{2 0 0 9}$ & $\mathbf{2 0 1 0}$ & $\mathbf{2 0 1 1}$ & $\mathbf{2 0 1 2}$ & $\mathbf{2 0 1 3}$ & $\mathbf{2 0 1 4}$ & $\mathbf{2 0 1 5}$ \\
\hline Mali & 3 & 23 & 15 & 8 & 13 & 23 & 35 & 16 & 21 & 45 & 23 \\
Côte d'Ivoire & 4 & 7 & 0 & 2 & 6 & 62 & 49 & 35 & 25 & 63 & 13 \\
Sénégal & 8 & 8 & 17 & 3 & 4 & 2 & 18 & 4 & 6 & 12 & 22 \\
Burkina Faso & 1 & 3 & 5 & 9 & 8 & 47 & 4 & 12 & 10 & 4 & 16 \\
\hline
\end{tabular}

Source: Europhyt 2005-2015

As economic consequences, interceptions of exports have caused the loss of the mango sector in West Africa, 17.22 billion CFA Francs between 2004 and 2015. Losses by interception are estimated at 19680000 FCFA or 30000 Euros (ECOWAS, 2012) and losses in 2012 alone were valued at CFA 1.83 billion. Rejections represent a very significant shortfall for exporting countries. The rejection of a range of mangoes from Europe would cost between 1 and 1.5 million FCFA to the African exporter according to a joint FAO / CILSS report in 2003. 


\section{MATERIALS and METHODS of the STUDY}

To analyze the failures of developing countries' export markets and African mangoes in particular, we will rely on author work on export barriers and market failure. Analysis by hypothetico-deductive and hypothetico-inductive methods will allow us to draw conclusions.

\subsection{Review of the literature on European barriers to exports of developing countries}

Authors such as Ortiz J. A. and Ortiz R. F. (2010), have done very important work on the identification of export barriers for SMEs in four (4) categories. The first category of barriers could be the lack of information on export markets. Yang, Leone and Alden (1992) find that the barriers related to the lack of information on export markets are the only ones, among all the categories of barriers, that vary considerably. And according to Aharoni (1966) the lack of knowledge of foreign markets constitutes an important barrier to the commitment of organizations in international activity. For Hernando Moreno, (1993) the availability of information on external markets is generally quite rare, and the cost of this information is high for a particular agent. The lack of information on market opportunities for the product was also mentioned as an obstacle, by Westhead, Wright and Ucbasaran (2002). For authors like Johanson and Valhne (1977) it is rather the lack of knowledge of the steps to follow in the export process that represent the major obstacles to exporting. Ignorance of available export subsidies according to Kedia and Chhokar, 1986; and the lack of knowledge about the economic benefits of exporting according to Welch and Wiedersheim-Paul, 1977, Axinn, 1985, can be significant obstacles to business engagement in export activities. In the second category of export barriers, Ortiz JA and Ortiz RF (2008) rank the company's lack of production capacity (Leonidou, 1995b, Westhead, Wright and Ucbasaran, 2002), difficulties in financing exports and the lack of means to carry out market research (Ramaswami and Yang, 1990). There is a third category of barriers that is related to the export process. In this category of obstacles, the complexity of documentation or approaches related to export transactions as barriers to firm exports supported by authors such as Naidu and Rao (1993), Katsikeas and Morgan (1994), Leonidou (1995b) or Moini (1997), the difficulty of finding a reliable distributor or adequate distribution channels (Karakaya 1993, Katsikeas and Morgan 1994, Leonidou 1995b, Da Silva 2001, Hise 2001), exports that may be either tariff barriers according to Barker and Kaynak, (1992) or are non-tariff barriers according to Leonidou, (1995b) like standardization and approval of export products, sanitary and phytosanitary regulations according to Kedia and Chhokar , (1986), Keng and Jiuan, (1989) or trade barriers due to high transportation and freight costs (Katsikeas and Morgan 1994, Leonidou 1995b) o u lack of transport service to the targeted market Da Silva (2001). Ortiz J. A. and Ortiz R. F. (2010) identified a last category of barriers considered to be exogenous variables. Among the barriers in this category are the foreign competition championed by Ramaswami and Yang (1990), the risk related to exchange rate fluctuations (Leonidou, 1995b) when it is an unfavorable fluctuation. There is some work devoted to the empirical analysis of the phenomenon of rejections. The work of Abdelhakim Hammoudi and al (2010), Rios and al. (2008), Shafaeddin, 2007, are the ones that caught the most attention.

These authors consider rejections as indicators of difficulties of access for developing countries to the markets of developed countries. For Shafaeddin (2007), the main cause of rejection at the border of the destination country is the lack of control at the port of departure in the country of origin and at the farm level. Abdelhakim Hammoudi and al (2010) showed that discards tend to increase, particularly with regard to West African products and taking into account the increase in the number of notifications, they showed how discards can to be 
considered as proof of the growing importance of SPS measures at European level, and therefore of the potential barriers to exporting African products to European countries.

\subsection{Theoretical causes of market failure}

High transaction costs, market power, imperfect information and signal are identified as key theoretical causes

\subsubsection{The problem of high transaction costs and market power}

The problem of transaction costs as a barrier to market efficiency has been the subject of numerous studies, including those of Coase (1960) and North (1994). According to Coase (1960), carrying out a transaction on the market requires many expensive operations, namely the search for information, negotiations, the formulation of contracts and the verifications necessary to ensure compliance by both parties. The work of North (1994) has highlighted in the transaction costs the existence of a part of unobservable costs said to be difficult to quantify, which are generally realized before the transaction, such as, for example, the costs of information and research on availability of the good or service (time and energy spent for example), and on the other hand quantifiable observable costs that occur at the time after completion of the transaction such as transfer costs of property rights. Market power has rarely been the subject of theoretical debate by economists, it is rather its consequences, particularly the inefficiencies it generates in markets that are the subject of much debate to this day. Pigou (1941) remarks that in the case of a commodity produced by a monopoly holding a market power, the limitation of the price can, by preventing it from seeking his gain by the increase of prices, force him to seek it by increasing sales.

\subsubsection{Imperfect information problems and quality signal}

In 1970, Akerlof showed that in a used car market the seller is generally more informed about the condition of the vehicle than the buyer. The ill-informed, but rational buyer, commits himself to buying the vehicle at a low price to compensate for his probability of falling on a vehicle in poor condition.

This purchase price of a very low level will not encourage sellers to offer the right vehicles but rather the bad ones. Such a situation increases the likelihood of buying a wrong vehicle and forces buyers to demand a lower price. The bad vehicles will gradually invade the market and the permanent falling requirements of buyers' prices will result in the total disappearance of the right vehicles on the market. The phenomenon could continue until the stoppage of any vehicle exchange on the markets when the probability of getting a wrong vehicle becomes very strong.

The theory of Akerlof can be formulated mathematically according to its main basic assumptions as follows: (H1) on the market two types of vehicles coexist: those of good quality in proportion $\mathrm{p}$ and those of poor quality in proportion 1-p ; (H2) sellers of good quality vehicles, the proportion $\mathrm{p}$, only agree to sell their vehicles at a price greater than or equal to $\mathrm{Pb}$ (good quality vehicles price); (H3) sellers of vehicles of poor quality, the proportion 1-p, do not agree to sell their vehicles only at a price Pm (poor quality vehicles price), $\mathrm{Pm}<\mathrm{Pb}$; (H4) buyers are not able to differentiate between two types of used vehicles namely the good ones of the bad ones, however they know that there are poor quality vehicles in proportion (1-p) and are also willing to pay a price $\mathrm{px} \geq \mathrm{Pb}$ for a good quality vehicle and a maximum price $\mathrm{px}{ }^{\prime}=\mathrm{Pm}$ for a poor quality vehicle. 
There are three possible equilibria:(i) a first equilibrium where the equilibrium price $\mathrm{px}=\mathrm{Pm}<\mathrm{Pb}$ and only the poor vehicles will be sold. As hypotheses of first balance we suppose that the salesmen know the quality of the vehicles which they propose for sale whereas the buyers have no way to observe this quality; the sellers here will propose vehicles of good quality only if the price equilibrium px is above $\mathrm{Pb}$; if the equilibrium price is lower than $\mathrm{Pb}$ buyers therefore know that all the vehicles they are offered are necessarily of poor quality and they will therefore accept to buy them only if the price is less than or equal to Pm; if now the equilibrium price $\mathrm{px}$ is greater than or equal to $\mathrm{Pb}$ the two types of vehicles will be offered for sale and the buyers will therefore consider that a vehicle is worth $p P b+(1-p) P m$; (ii) a second equilibrium where the equilibrium price $\mathrm{px}=\mathrm{pPb}+(1-\mathrm{p}) \mathrm{Pm} \geq \mathrm{Pb}$ and the two types of vehicles are sold; here it is assumed that neither sellers nor buyers can observe the quality of the vehicles; this equilibrium is only viable if $\mathrm{pPb}+(1-\mathrm{p}) \mathrm{Pm} \geq \mathrm{Pb}$; in the opposite case, the only balance is the first, where the bad vehicles have driven the good ones; (iii) a third equilibrium where there is an institution that sells certification to sellers that allows them to report to buyers the good quality of the vehicles they offer on the market; for a high price $\mathrm{px} \geq \mathrm{Pb}$ only one good quality vehicles are sold at the $\mathrm{pPb}$ price otherwise for a price $\mathrm{px}^{\prime}=\mathrm{Pm}<\mathrm{Pb}$ only the poor quality vehicles are sold at the price $(1-\mathrm{p}) \mathrm{Pm}$;

in addition to the problem of adverse selection, the work of Akerlof (1970) highlights the problem of the signal that the market of used vehicles can very badly run for lack of means for the well-informed seller to report the quality from the vehicle he sells to the misinformed buyer. However, it is the work of Spence (1975) who, in addition to confirming those of Akerlof (1970), draws our attention to the fact that the signal always involves a high cost which can reduce the seller's incentives to reveal the information to the buyer.

\section{RESULTS OBTAINED FROM THE STUDY AND DISCUSSIONS}

In this section we are talking about justifying the extent to which the theoretical causes of market failure in general may well represent the key determinants of the failure of mango export markets in West Africa.

\subsection{The different types of mango export contracts existing in West Africa}

To finance mango collection and export campaigns to Europe, African exporters are often forced to turn to trusted European partners with whom they can co-finance export activities as part of a partnership said "win-win partnership". European importers in turn will develop partnerships with the distribution stores for the sale of mangoes to European consumers. This type of partnership is usually achieved through the signing of transaction contracts between exporters and importers and between importers and distribution stores.

In West Africa, the different contracts between exporters and importers are mostly standardized cost-shared and / or shared-profit contracts and sales commission contracts. For mangoes, standardized cost-shared and / or shared-benefit contracts are found in Burkina Faso, Senegal, Côte d'Ivoire and Mali with some slight differences in their development. In this contract, it is generally provided that the importer guarantees a floor price, FOB price from the port of shipment, paid upon receipt of the bill of lading and that he will take care of all the cost of transportation from end to end(road / rail / maritime) that he pays directly to the logistics company. This contract provides that upon arrival of the container at destination, the importer makes a financial statement, by establishing a revenue and expense account to share the profits with the exporter. This type of contract is close to sharecropping and is most common in West Africa for fruit and vegetables for export to Europe. In a second type of firm contract for the export of mangoes, the importer is expected to pay the exporter an advance 
for the removal of a number of known advance containers during the campaign, in order to pre-finance the purchase of the mango and its packaging. Thus, it directly pays the logistics company, the transportation costs from end to end. At the end of the season, the importer sends the financial statement and shares the profits with the exporter, after deduction of all the costs incurred up to the final consignee in Europe.

Given the seasonal nature of mangoes, they must be imported from different countries to ensure year-round supply. The selling price can thus vary considerably. In times of plenty, the price can drop tremendously, thus prompting buyers to be very demanding on quality. The situation is reversed in times of lack. As a result of the fluctuating nature of prices and quality, some European importers generally avoid engaging in volume and fixed price contracts. They most often agree to engage in sales commission contracts. Mangoes received from exporters are sold by importers to European retailers and supermarkets by deducting a commission of 8 to $10 \%$ of the amount paid to the exporter.

\subsection{The problem of high transaction costs and market power}

The complete contract is the one considered to be an optimal contract. It is difficult for importers and exporters of mangoes to reach the conclusion of a complete contract because of the fact that in the transactions certain costs remain implicit and difficult to observe and quantify before and even after the signature of the contract. The effort made by exporters in finding information on varieties and the availability of mango stocks in the different localities is an unobservable act by importers with costs that are difficult to take into account in the contract. Thus, when the costs of information retrieval are not taken into account in the contract and it is after the exchange that they occur, they can raise the cost of costs and abnormally lower the profit of one of the partners. . This could jeopardize the win-win partnership and limit each other's commitment to other future contracts. Transaction costs, even if they are often recorded in documents such as receipts and invoices, remain unobservable by exporters; and importers may, if necessary, lie on their exact amounts by raising them to defraud the amount of actual profits. The importer may overcharge or be abnormally issued receipts or invoices containing fictitious expenses that raise the cost of mango import. The same fraudulent behavior can be adopted by the exporter when the transaction costs are unobservable by the importer. The exporter could also lie about the exact amounts of these transaction costs by overcharging or being abnormally issued receipts or invoices. In any case, in the different types of contracts that we have studied above, the profit to be shared will become less important and the contract will no longer be an incentive for one of the partners, which could lead to its rupture and a loss for everybody.

Aoufa E. (2009) has shown that the transaction costs of a container of mangoes from packaging stations in Burkina Faso and Mali to distribution stores in Europe (Rungis) can reach 15 million CFA francs and include mainly the cost of the mango delivered to the packing station, the cost of packaging, the costs of land and sea transport, as well as the costs of transit, storage, loading and unloading costs at the port of Europe, the costs of forwarding costs to the European wholesaler, commission fees on sales if applicable. This amount seems very high and out of reach of the stock exchange of the average exporter of Burkina Faso and Mali. Also, as additional transaction costs, discards can result in high transportation costs for re-shipping the product, re-export costs, and even the costs of product destruction when borne by the exporter. Pre-financing contracts by importers, cost-sharing contracts (sharecropping) and sales commission contracts are all contracts that tacitly give European importers market power to African exporters of mangoes. In the type of pre-financing contract of the campaign by the European importer, the latter is the one who invests the most, thus taking more risks, 
and the only one to negotiate with the distribution shops for the obtaining of a cheap in Europe. The African exporter is price takers vis-à-vis what would result from the agreement between the European importer and the final actors of the import namely the distribution stores. Neither does it have the means to call into question the transaction costs agreed between its importing direct partner and these distribution stores in Europe. The low financial capacity of African exporters to pay the transaction costs (transport, handling, maintenance, etc.) related to the transport of cargoes of mangoes to the European borders, tacitly confers on the European importer a power of because it is he who has to find all the financial resources necessary to pay these transaction costs so that the export market can be realized.

\subsection{Imperfect information problems and quality signal}

Due to the fluctuating nature of prices, quality, supply and demand of mangoes in European markets, as well as interceptions and referrals of cargoes of mangoes en route, African exporters often imprecise knowledge of the prices, quality and quantities of their mangoes actually sold in these European markets. This often leads them to doubt the good faith of European importers as to the prices and quantities of the sale of these mangoes to distribution stores.

Table 3. Fluctuations in import prices of mangoes from 2008 to 2012 (in Euros)

\begin{tabular}{lccc}
\hline Pays /Années & $\mathbf{2 0 0 8}$ & $\mathbf{2 0 1 0}$ & $\mathbf{2 0 1 2}$ \\
\hline Cote d'Ivoire & 1,10 & 0,90 & 0,88 \\
Sénégal & 1,35 & 0,95 & 1,53 \\
Mali & 1,34 & 0,95 & 1,17 \\
Burkina Faso & 2,37 & 1,40 & 2,00 \\
\hline
\end{tabular}

Source : COLEACP, 2013

If they were accessible to African exporters, contracts, pro-forma and / or settlement invoices, importers' order letters with distribution stores in Europe would be reliable price and information the quality and quantities of mangoes sold at these stores. Unfortunately, these documents are very often confidential and difficult for exporters to access. And even if they were accessible, the African exporter would have no way of knowing that these documents are authentic and not tampered with. To obtain this economic information reliably African exporters are obliged to carry out studies and surveys on the European markets and this most often at their own expense so that the information is not biased to the benefit of importers. In the case of export, European importers often have unclear and uncertain knowledge of mango stocks available in the different exporting countries. Varieties and areas of mangos produced by locality often remain inaccurate information for importers. This does not allow them a good forecast or a planning of orders and the necessary logistics (means of transport and packing of mangoes). As a result, poor forecasting and planning due to imperfect information from importers could lead to an underestimation or overestimation of available stocks and varieties but also the means of transport and packaging to be provided for the implementation. mango market. This could lead to waste of resources in case of overestimation of stocks and the means of transport and packaging to deploy for the removal and conditioning of stocks. In the case of the sales commission, it is the importers who organize the transactions with the distribution stores and they do not need to trade large quantities of imported mangoes on the European market to make good commissions even if the commission rate between 8 and $10 \%$ is well known to the exporter. Mango is a perishable product and for export its purchase price generally known to the exporter is the floor price. Fluctuations in the upward price on the European market are not information well known by the exporter. In the context of well-organized consensual fraud, transactions 
between the importer and the distribution stores may well be at price levels consistent with the floor price, or slightly higher when in reality they have occurred at high price levels benefiting the importer who in addition to his commission will share the margins with distributors against issuing false trade documents for the balance sheet with the exporter remained in Africa. All SPS control and information equipment, international standards and regulations to provide quality in accordance with the requirements of the international market represent a means of signaling quality to importers from the country of shipment of cargoes to host country. However, the lack of control equipment and the low level of education and training of African exporters for the use of quality control equipment does not allow them to control the quality of the mangoes they sell to European importers. . The contract between the European importer and the African exporter can be poorly executed for lack of means for the latter to be able to report the quality of the mangoes that he proposes to the importer. Indeed, in the case of firm contracts of the type "pre-financing of the campaign" by the importer by advances of sums of money to the exporter for the purchase and packaging of conventional mangoes in packaging, the African exporters may lack the means to signal to importers the quality of mangoes before they are shipped to the countries of Europe; This does not minimize the number of interceptions and releases of cargoes of mangoes at the borders of European countries representing huge economic losses for importers likely to degrade the confidence and reputation of exporters and subsequently a probable break of their contracts. The implementation of commercial certifications, in particular the trade certifications Bio-equitable, EUREPGAP and Global GAP, for example, allows exporters to point out to importers the good quality of mangoes they sell for European markets and to minimize interceptions at borders.

However, the bias may remain in the sense that the lack of capacity of exporters, and producers to invest in certification, may lead the importer to finance exporters and producers to obtain these certifications but under conditions that can implicitly and financially ruin them. For example, fraudulently recover more than the amounts invested in the acquisition of these certifications by false invoices of the expenses in the sales of the mangoes that they control on the European markets. Also, the bio-fair certification or Global Gap is only a belief for the European consumers compared to the guarantee of the quality of the mango that they consume. The mangoes collected by the exporter and supposed certified organic may not be in reality but rather come from untreated orchards that produce conventional mango but sold on markets in the organic state.

Consider $Q$, the quantity of mangoes for export, $p x$ the equilibrium import price, and let q1 be the quantity of mangos of good quality, $q 2$ be the quantity of mangos of poor quality. We can write $Q=q 1+q 2$. We thus note two types of mango quality types on the market: those of good quality in proportion $p=q 1 / Q$ and those of poor quality in proportion $1-p=q 2 / Q$. So, by transposing the Akerlof model, for the analysis of the failures of the export market of mango we obtain the following results: a first equilibrium where the equilibrium price $p x=P m<P b$ and only the mangos of poor quality will be sold to European importers, a second equilibrium where the equilibrium price $p x=p P b+(1-p) P m \geq P b$ and the two types of mango quality are sold to European importers, a third equilibrium where for a high price $p x \geq P b$ only the good quality mangoes are sold at the price $p P b$ otherwise for a price $p x^{\prime}=P m<P b$ only the mangos of poor quality are sold at the price (1-p) Pm. This last equilibrium is that of an exporter indifferent to the risks. He can be riscophobic when he only sells good quality mangos for a market price $\geq p x P b$ or riscophilous when he sells only poor quality mangoes at a market equilibrium price $p x{ }^{\prime}=P m<P b$. The expected gain of the mango exporter in the case of the first equilibrium is (1-p) $P m Q$. In the second equilibrium its 
expected gain is $(1-p) P m Q+p P b Q=(p P b+P m-p P m) Q$. In the case of a third equilibrium where the equilibrium price $p x \geq P b$ only the good quality mangos are sold at $p P b Q$ and the expected gain is $p P b Q$. In the opposite case for an equilibrium price $p x{ }^{\prime}=P m<P b$ only the poor quality mangoes are sold at (1-p) $P m Q$ and the expected gain (1-p) $P m Q$. For the gains obtained according to the types of exporters of mangoes encountered in the field and according to their level of information with regard to importers, five situations of probable earnings are conceivable: 1) riscophobic exporters informed of the good quality of the mangoes they propose and that they report to the importers will obtain a hoped gain $p P b Q$ for $p x>P b ; 2)$ exporters indifferent to the risks but informed of the quality of the mango which they propose to the importers who ignore it, will obtain a hoped gain $(p P b+P m-p P m) Q$ for $p x \geq P b ; 3$ ) exporters indifferent to the risks but unaware, like the importers, of the quality of the mango they propose to them, will obtain a hoped for gain $(p P b+P m-p P m) Q$ for $p x \geq P b ; 4)$ riscophilous exporters who know as importers that the proposed mangoes are in poor quality will get a hoped gain (1-p) $P m Q$ for $p x=P m<P b$; 5) riscophilous exporters who know that a proportion of the mangoes they offer are in poor quality, unlike importers who ignore it will get $(p P b+P m-p P m) Q$ as expected gain for $p x \geq P b$.

\subsection{Discussion of results achieved, policy recommendations economic}

With only $10 \%$ to $15 \%$ of export quantities for controls, exporters and importers, who are often aware of the proportions of good or bad quality mangoes in containers, make the lottery hoping that the quantities samples taken for the checks come from batches of good quality mangos. If there are levies for mango cargoes control (in situation 4), these cargoes will not cross European borders. The expected gain at this moment is zero. If control levies fall on high quality mango lots, the expected gains of informed riscophobic exporters, indifferent exporters and riscophilous exporters will remain unchanged.

On the other hand, when the levies for control fall by chance on the mangos of poor quality, the gain of the riscophilous exporters and indifferent to the risks become $p P b Q$ if the exporter or his representative is on the spot at the border to remove the batches of mangos of poor quality from the container, and would be zero when the exporter or his representative is not on the spot at the border to remove batches of mangoes of poor quality and at this moment the entire container of mangoes is lost. In the case of the Akerlof model, riscophilous exporters aware of the proportion of the poor quality of mangoes offered, and exporters indifferent to the informed or ignoring the quality of mangoes are the ones that maximize the expected gain. Thus, we could clearly argue that in the face of uncertainties and risks, the failure of mango export markets to Europe would be linked to a problem of adverse selection on the part of riscophilous exporters. Indeed, when the equilibrium price $p x=P m<P b$, they will only sell to European importers poor mangoes. But as there are barriers to the quality control of these mangoes at European borders, the riscophilous exporter remains highly exposed to systematic interception and rejection of mango cargoes. The market could indeed fail for him when the samples levies at the borders fall on the proportions of mangos of poor quality and of which he is aware. On the other hand, when the equilibrium price $p x>P b$ the riscophobic exporters informed on the good quality of their mango and obtaining a hoped gain $p P b Q$ may want to signal the good quality of mangoes that they propose to the importers. These mangoes of good quality will inevitably cross the control barriers regardless of the level of sampling.

For $p x \geq P b$, the riscophilous exporters aware of the proportion of the poor quality of mangoes proposed will obtain a higher expected gain $(p P b+P m-p P m) Q$ than that of the riscophobic exporter $p P b Q$. 


\section{CONCLUSIONS and RECOMMENDATIONS of ECONOMIC POLICIES}

In standardized, cost-shared, shared-profit contracts, the incentives of the different parties to find perfect information about the attributes and elements of the contract are strong because everyone wants to be reassured that there is genuine equity in the distribution of profits and expenses. As a result, the importer or exporter will seek to know the nature and structure of transaction costs in both domestic and international markets. Each one taking all the necessary precautions to avoid any scam by the other by verifying the effectiveness of all the elements of the contract. Cost-shared and shared-cost standardized firm contracts are contracts for transparency and the reduction of transaction fraud. The implementation of this type of contract for the export of mangoes should be encouraged. On the other hand, standardized firm contracts with unevenly distributed costs and benefits (pre-financing of importers) are contracts of incentives for inertia and darkening of the international market for African exporters. These types of contracts represent prime areas for the development of fraud and opportunism for European importers. Indeed, the European importer who prefers the mango collection campaign and its transport to Europe is the main investor who runs more risk in the investment of its capital. Through its commitment to the pre-financing of the entire campaign, the European importer can prevent his African partner from knowing all the motives of mango transactions that occur afterwards, on European soil since he has market power vis-à-vis of the latter forced to under-inform and pay the risks. The sales commission contract may lead to consensual fraud between the importer and the distribution stores to the detriment of the African exporter. The latter, even aware of the existence of such fraud or complicity between its importing partner and the retail stores, will not be able on its own to reverse this kind of opportunistic behavior that is considered consensual. . The choice of the type of contract by the exporter depends on his level of commitment to the risks. If he hates to take risks (riscophobic agent), he will engage in standardized export contracts on prefinancing almost total campaign and harvest by the European importer with advances. If he is risk neutral (indifferent agent) he will engage in standardized contracts with shared costs and benefits.

On the other hand if he likes to take too much risk (riscophilous agent) he will engage in sales commissions with importers. Interceptions and rejections of mango packages related to the non-compliance of export documents (absence of phytosanitary certificates, false information issued, document traffic, etc.) reflect the exporters' expediency, namely their obvious desire to The quality control sample at European borders covering only 10 to $15 \%$ of export cargoes of mangoes is an incentive for African riscophile exporters on the border. fraud to maximize their gain by hoping to slip through the cracks of control by counting that these control fall on their batches of good quality mangos among the bad ones. To combat this type of opportunism, the control sample deserves to be enlarged; the development and implementation of a system capable of controlling all cargoes dedicated to exports would be the best alternative.

\section{REFERENCES}

AKERLOF, G. (1970). «The Market for "Lemons": Quality Incertainty and the Market Mecanism » Quarterly Journal of Economics: 488-500.

AOUFA E. (2009). « Etude corridors pour l'exportation des mangues du Mali et du Burkina Faso vers l'Union Européenne », Banque Mondiale P45-46

ARTEAGA-ORTIZ, J., AND FERNANDEZ-ORTIZ, R. (2010). 'Why Don't We Use the Same Export Barrier 
Measurement Scale: An Empirical Analysis in Small and Medium-Sized Enterprises',

Journal of Small Business Management, vol. 48, no. 3: 395-420

AXINN, C.N. (1985), An Examination of factors that Influence Export Involvement, PhD thesis UMI, Michigan.

COASE R. (1960) :«The Problem of Social Cost , Journal of law and Economics», vol.3, 1960.

HAMMOUDI, A., GRAZIA C.ET GIRAUD-HERAUD E. (2010), "Hétérogénéité des standards de sécurité sanitaire des aliments : Quelles stratégies pour les filières d'exportation des PED ?, AFD, Paris. P38-44

HISE, R.T. (2001), « Overcoming exporting barriers to Mexico », Marketing Manage- ment, vol. $10, \mathrm{n}^{\mathrm{o}} 1$, p. 52-55.

JOHANSSON, J. ET VAHLNE J.E. (1977), «The internationalization process of the firm : a model of knowledge development and increasing foreign market commit- ments », Journal of International Business studies, vol. 8, p. 23-32.

LEONIDOU, L.C. (1995a), « Empirical research on export barriers : review, assessment, and synthesis », Journal of International Management, vol. 3, p. 29-43.

LEONIDOU, L.C. (1995b), « Export barriers : non-exporters perceptions », International Marketing Review, vol. 2, $\mathrm{n}^{\mathrm{o}} 1$.

KARAKAYA,F.(1993)«Barriers to entry in international markets», Journal of global Marketing, vol.7, $\mathrm{n}^{\mathrm{o}} 1, \mathrm{p} 7-24$

KATSIKEAS, C.S. ET MORGAN R.E. (1994) «Differences in perceptions of exporting problems based on firm size and export market experience ", European Journal of Marketing, vol. 28, $\mathrm{n}^{\mathrm{o}}$ 5, p. 17-35.

Kedia, B.L. et chhokaR J. (1986), «Factors inhibiting export performance of firms : an empirical investigation », Management International Review, vol. 26, p. 33-43.

NORTH, D. (1992). Transaction costs, institutions, and economic performance. San Francisco, CA: ICS Press. p. 5.

RIOS, L. B. D. ET JAFFEES. (2008), « Barrier, Catalyst, or Distraction? Standards, Competitiveness, and Africa's Groundnut Exports to Europe », The World Bank,. P3852

SHAFAEDDIN, M. (2007), « The Cost of Compliance with Sanitary and Phytosanitary Measures in Low-income Countries: a Strategy for Reorganization of the Supply Chain », Third World Network, .

SPENCE, A. M. (1974). Market Signalling : Informational Transfer in Hiring and Related Screening Processes. Cambridge (Massachusetts), Harvard University Press.

WESTHEAD, P., WRIGHT M. ET UCBASARAN D. (2002), « International market selection strategies selected by micro and small firms », The International Journal of Management science, vol. 30, p. 51-68. 
WIEDERSHEIM-PAUL, F., OLSON H.C. ET WELCH L.S. (1978), « Pre-export activity : the first step in internationalization », Journal of International Business studies, vol. 9, $\mathrm{n}^{\mathrm{o}} 1, \mathrm{p} .47-58$.

YANG,Y.S. (1988), An Export Behavior Model of small firms : Identifying Potential and Latent Exporters among small and Medium Manufactures, $\mathrm{PhD}$ thesis, UMI, Michigan. 